\title{
MICHAE SIKORA
}

(Katowice)

\section{SENS DZIEJÓW I KENOZA \\ W MYŚLI AUGUSTA CIESZKOWSKIEGO \\ I WŁODZIMIERZA SOŁOWJOWA}

\begin{abstract}
Wstęp
W filozofii europejskiej dziewiętnaste stulecie było okresem burzliwych debat, inspirowanych Heglowską historiozofią i mesjanizmem. August Cieszkowski i Włodzimierz Sołowjow reprezentowali w zagadnieniach filozofii dziejów i filozofii religii podobne przemyślenia. Celem niniejszej pracy jest porównanie twórczości filozofów, zwracając szczególną uwagę na tematykę objaśniającą prawidła dialek-

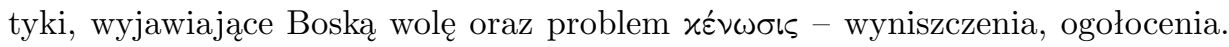
Obydwie kwestie, równie ciekawe i istotne, prowadzą do podobnych konkluzji zarówno w przypadku polskiego myśliciela katolickiego, jak i rosyjskiego mędrca przynależnego do tradycji Kościoła prawosławnego. Wychodząc od pojęcia czynu w rozumieniu Hegla, postaram się przedstawić, w jakim stopniu ten ważki termin dla Cieszkowskiego i Sołowjowa kształtował ich oryginalne przemyślenia.
\end{abstract}

\section{Istota czynu}

W Fenomenologii ducha świadomość nieszczęśliwa jest w sobie rozdwojona, z sobą niepojednana. Jej nieszczęsny binaryzm wynika z potrzeby posiadania innej świadomości, do której może się zwracać. To podwojenie świadomości uprzytamnia popadnięcie w egzystencjalną pułapkę zależności. Próby pojednania świadomości rozdwojonej potęgują przeciwieństwo, odsuwając szansę ponownego zjednania. „Ujednostkowienie kończy się w przyrodzie śmiercią, w społeczeństwie alie- 
nacją i osamotnieniem, w poznaniu - świadomością nieszczęśliwą. Hegel wiedział oczywiście, że może zanegować negatywne konsekwencje ujednostkowienia tylko w poznaniu, w sferze myśli: po całym procesie historycznym człowiek powraca do pierwotnej jedności ze światem, jednoczy się z nim, ale tylko idealnie" ${ }^{1}$. Relacja ponownego złączenia, usilnego zniwelowania wszelkich pęknięć, wyznacza pozycję poddańczą wobec drugiej świadomości, z którą mamy się zespolić. Cenę, jaką płaci świadomość nieszczęśliwa, jest zniewolenie, w zależności, czy wypływa z interpretacji religijnej bądź sekularnej, może uosabiać niewolę ideologiczną, pozycję klasową, sytuację państwową (albo - mówiąc szerzej - moment historyczny, który należy przekroczyć). Ludzkie życie nie ma żywić się projekcją marzeń wynikających z rozpamiętywania przeszłości, lub rzutowania ich w przyszłość, ale aktywnie walczyć o nastanie upragnionego stanu idealnego. Właśnie działanie jest próbą ulepszenia wypaczonej rzeczywistości, usuwania niedostatków, przywracania ładu dla wszystkich. W ten sposób August Cieszkowski uznawał możliwość twórczego rozwinięcia heglizmu ${ }^{2}$, zamkniętego i rozgrywającego się na poziomie idealnym. „I właśnie dopiero zaprzeczenie heglowskiego zaprzeczenia świata materialnego, zmysłowości, jednostkowości, zaprzeczenie ogólności bezwzględnie podporządkowującej sobie indywidualność i zaprzeczenie jedni w sposób czysto spekulatywny, tylko myślowy, godzącej podmiot z przedmiotem - wszystko to ukonstytuować może prawdziwą pozytywność materialnego, społecznego, kulturowego świata, budować wychodzącą z empirii realność ogólności, harmonizującą człowieka i wspólnotę i tworzyć rzeczywistą jednię podmiotu i świata. Stać się to może tylko przez jednoczenie idei z materialną i społeczną praktyką w procesie indywidualnej i wspólnotowej kreacji” ${ }^{3}$. Bieg dziejów należy rozpatrywać poprzez czyn. Czyny są motorem społecznego postępu.

1 J. Kuczyński, Homo creator. Wstęp do dialektyki czlowieka, Warszawa 1976, s. 35.

2 W jakim stopniu Cieszkowski był heglistą, pozostaje tematem do dyskusji. Jak zauważa Lech Stachurski: „Dla Cieszkowskiego stanowisko Hegla jest więc stanowiskiem przedostatnim, które domaga się dalszej syntezy ze względu na postęp ducha". w: L. Stachurski, Heglizm polski: elementy strukturalne, Warszawa 1998, s. 25.

Odmienne stanowisko zajmuje Marek N. Jakubowski: „Zarówno pytanie o sens jak i warunki rozwiązania tego problemu [możliwości skonceptualizowania teorii z praktyką] w sposób jednoznaczny lokują takie rozważania przede wszystkim na poziomie historiozoficznym. Nie było zaś wówczas historiozofii bardziej imponującej, bardziej »naukowej«, bardziej atrakcyjnej więc ponad tą, którą stworzył Hegel. Jednakże sam fakt, że historiozofia ta zatrzymała swe poznanie w momencie, w którym dla filozofów polskich [XIX stulecia] ujawniło się dopiero najbardziej ich interesujące pytanie, wskazał na jej istotne ograniczenia". w: M.N. Jakubowski, Historiozofia jako filozofia praktyczna. Hegel a polska filozofia czynu, Bydgoszcz 1991, s. 102.

Jeszcze inaczej zapatruje się Andrzej Wawrzynowicz: „Ogólny stosunek Cieszkowskiego do Heglowskiej koncepcji logiki dziejów polega więc raczej na próbie pozytywnego dotrzymania kroku Heglowskim postulatom spekulatywnego ujęcia historii, niż na jednoznacznej negacji tych postulatów z perspektywy filozofii czynu, interpretowanej jako filozofia działania praktycznego, uzasadniająca hasła radykalnej przebudowy społecznej". w: A. Wawrzynowicz, Filozoficzne przeslanki holizmu historiozoficznego w myśli Augusta Cieszkowskiego, Poznań 2010, s. 73.

3 J. Kuczyński, Homo Creator. Wstęp do dialektyki czlowieka, wyd. cyt., s. 40. 
Zapowiedziana przez Cieszkowskiego finalna epoka dziejów dopełni pozostałe, windując osiągnięte przezeń przemyślenia na wyższy poziom wiedzy. Każda jednostka to narzędzie Ducha Świętego, która - pod jego wpływem - ma zjednoczyć wszystkich w ponadwyznaniowej religii, wywodzącej się z Kościoła katolickiego. Filozof godził dwie wizje (radykalnie odmienne) czasu historycznego. Pierwsza, wyznaczała linearny (a zatem nie skokowy) charakter przekształceń społecznych, przechodzących trzy cykle, zachowując ciągłość historyczną. Druga, to dynamiczne (ale nie rewolucyjne ${ }^{4}$ ) przybliżanie się do idealnego horyzontu, zapewniającego zbawienie wszystkim (które wpierw należało samemu sobie zapewnić).

Zasada czynu to przejaw subiektywności ludzkiej w obiektywnym świecie. Czyny są zdarzeniami poteoretycznymi, określającymi stopień dojrzałości ludzkiej. Doprowadzenie mas do samowiedzy, uwypukla siłę pokonującą przeciwieństwa, przyjmując, że takie działania nie są bezcelowe, a realizują wyższy zamysł

4 Cieszkowski wielokrotnie przestrzegał przed zrywami rewolucyjnymi, godzącymi w ład moralny i porządek społeczny. Optował za stabilną, przemyślaną przemianą. Reformizmem społecznym, sukcesywnie posuwającym się naprzód. Postęp nie miał być zerwaniem z tradycją, ale wznoszeniu na jej kanwie nowoczesnego narodu. Każda rewolucja była destrukcją, swoistą katastrofą, której opłakane skutki należało długo odbudowywać. Przestrzegał: „W tem właśnie mylicie się okropnie, iż sądzicie, jakoby Rewolucja mogła być kiedykolwiek przyczyna postępu, gdy tymczasem one niczem innem być nie mogą, jedno jego skutkiem fatalnym, wywołanym przez tych, którzy prawego postępu dobrowolniej uznać, lub przyznać nie chcieli. Są one jawnym występem na świat społeczny tego właśnie, co się we wnętrzu ducha już było spełniło, co się właśnie w organizmie zdrowo rozwijało, a co owszem Rewolucja wszelka, choćby przymusem wywołała, mniej lub więcej na dezorganizację naraża”. w: A. Cieszkowski, Ojcze nasz, Poznań 1922-1923, T. 2., s. 182.

W podobnym tonie, podkreślając sakralizację czynu, wypowiada się Piotr Bartula: „Przyszły ład nie powstanie z woli jakiegoś chwilowego centrum władzy posługującego się ideologią Królestwa Bożego, a tylko przez doskonalenie się wszystkich ludzi, powolną racjonalizację działania równoznaczną z sakralizacją stosunków społecznych. Dokonać się to może tylko i wyłącznie $\mathrm{w}$ zgodzie $\mathrm{z}$ 《ekonomią objawienia» i zgodnie z powolnym spełnianiem się w historii objawieniem Bożym. Czyn rewolucyjny jest w pełnym tego słowa znaczeniu heretycki, ponieważ zaprzecza ufności w naturalny, opatrznościowy bieg dziejów. (...) Próba przeprowadzenia jednorazowej akcji w celu osiągnięcia Królestwa Bożego i rozwiązania wszystkich problemów socjalnych zakończyć się musi wielkim nieszczęściem. Nie doprowadzi do postępu moralnego, lecz do demoralizacji i regresu cywilizacyjnego ludzkości. Metoda rewolucyjna automatycznie sprawia, że pierwotnie moralny, cel rewolucjonistów ulega upolitycznieniu i służy ostatecznie realizacji instynktu władzy”. w: P. Bartula, „Jako w niebie tak i na ziemi”: August Cieszkowski redivivus, Kraków 2006 , s. 60 .

Zgoła inaczej na sprawę rewolucji u Cieszkowskiego zapatruje się Marek N. Jakubowski, dowodząc semantycznej pojemności słowa prze-wrót. Eksplikuje, że Cieszkowski mógł przeczuwać nowe, dotychczas nie urobione historycznie pojęcie (r)ewolucji: „Otóż rzecz w tym, że Cieszkowski mówiąc «rewolucja» miał na myśli jedno z dwóch różnych zakresów pojęć. Po pierwsze więc: przewrót totalny obejmujący całokształt rzeczywistości - jego wynikiem jest powstanie całkowicie nowej jakości, która stanowi antytezę starej. Taka rewolucja dokonała się raz w dziejach ludzkich (sprawcą był Chrystus) i więcej już się nie powtórzy, jej wystąpienie przeczyłoby bowiem takiemu rozumieniu triady dialektycznej, jakie znajdujemy w pismach Cieszkowskiego. Po wtóre przewrót obejmujący pewne tylko sfery rzeczywistości - religię, naukę, sztukę, politykę. Takie rewolucje dokonały się już w ostatnich wiekach - ich wynikiem jest podważenie pewnych wartości, natomiast zasadniczo nie tworzyły one nowych (chociaż przygotowywały ich nadejście)". w: M.N. Jakubowski, Czyn, Przyszłość, Naród. Poglady filozoficzne Augusta Cieszkowskiego, Warszawa-Poznań 1989, s. 55. 
Boski. Pojmując wolność własną nie jako dar natury lecz łaskę Opatrzności, ludzie są w stanie przyjąć słuszny kierunek w ekspresji twórczej - oddolnej organizacji, dbającej o własność wspólną. Tak rozumiane działanie poszerza zakres dobra powszechnego. Czyn jest emanacją Boskiej woli, objawieniem zamysłu Absolutu. „Oto bowiem podmiot przyjmujący objawienie, tj. człowiek, pozostaje całkowicie bierny; jeśli jednak Bóg ma pozostać Absolutem, samo istnienie czegokolwiek nieabsolutnego musi być pojęte jako manifestacja Absolutu (w tradycyjnym języku chrześcijańskim mówi się o tym, że Bóg objawia się już w samym stworzeniu). Zakładając ścisły związek istnienia i działania, tj. uznając, że istnienie człowieka polega m.in. na ludzkim działaniu (nie jest możliwe istnienie niedziałające, nie można istnieć i nic-nie-robić), działalność poznawcza człowieka, będąca wyrazem/sposobem ludzkiego istnienia, jest manifestacją Boga. Koncepcja fenomenu przesyconego, który nie obejmowałby ludzkiej aktywności (w tym aktywności poznawczej), nadaje się do odrzucenia" ${ }^{5}$. Istotą czynu jest wypracowanie przyszłości przez byt, którego inspiracją jest projekt przyszłości i wola. Czyn zawiera w sobie formułę myślenia i wolę trwałej kreacji. „Jednostronność Bytu i Myśli skupiają się w Czynie, bo Czyn jest pomyślanym Bytem i bytująca Myślą" 6.

Epoka czynu - ostateczna epoka dziejów, odznacza się również duchowym wzmożeniem. Nauka ustąpi miejsca nowej religii. Znane z historii Kościoły zejdą się w jeden homogeniczny Kościół o zasięgu globalnym. Nieśmiertelny duch będzie wiódł żywot w ziemskiej społeczności. Czyn zatem posiada znaczący wpływ na proces udoskonalania społeczeństwa. Człowiek poprzez pracę zdobywa pozycję moralną - samodoskonali się wewnętrznie. Czyn okazuje się nie tylko altruistycznym tworzeniem na rzecz innych, ale także spełnianiem obowiązków wobec samego siebie. Takie rozwiązanie prowadzi do zharmonizowania interesów partykularnych z grupowymi (Cieszkowski uwspółcześnia pojęcie społecznej praxis ${ }^{7}$ ).

5 P. Sikora, Logos niepojęty. Analiza filozoficzna, Kraków 2010, s. 185.

6 A. Cieszkowski, Ojcze nasz, wyd. cyt., t. 2., s. 231.

7 Arystoteles „(...) wyznaczył zasadniczą granicę dzielącą poiesis i praxis. Różnica między tymi dwoma typami działań polega, zdaniem Stagiryty, na tym, że w pierwszym cel leży poza podmiotem, w drugim zaś jest zawarty w nim samym. Poiesis więc była konceptualizacją antycznej techniki produkcji, w których podmiot przetwarza z pomocą narzędzi zewnętrzny świat »natury«. Praxis natomiast nie oznacza przetwarzania świata zewnętrznego, lecz działanie, które zmienia, doskonali sam podmiot. Szczególnym przypadkiem takiego działania jest aktywność polityczna, która ukierunkowana na dobro ogólne realizowane w politei, rzeczywiście służy realizacji istoty człowieka jako zoon politikon". w: M.N. Jakubowski, Historiozofia jako filozofia praktyczna. Hegel a polska filozofia czynu, Bydgoszcz 1991, s. 14.

„Odnowiona” praxis oznaczałaby działalność na rzecz własną i - w konsekwencji - wszystkich. Praktyka społeczna tak pojmowana staje się obowiązkiem każdego, rodzajem służby publicznej. Społeczeństwo zintegrowane działaniem oznacza stan doskonałości w wymiarze wolicjonalnym (działalności praktycznej człowieka), wraz z wiedzą i uczuciem. „Według niego [tj. Ciesz- 
Udział w takiej wspólnocie pomagał też pokonywać osobiste trudności, aby stale piąć się w górę po szczeblach drabiny społecznej. Świat historyczny, pomniejszający stratyfikację społeczną, mógł starać się osiągnąć cel główny - uzyskanie wiecznej unii z Bogiem.

\section{Spełnienie dziejów}

Terrestrialna eschatologia Cieszkowskiego opisuje przekształcenie świata i ludzkości, ustanawiając Królestwo Boże na ziemi. Intelektualnym promotorem w poglądach objaśniających powstanie finalnego projektu Królestwa Bożego na Ziemi był dla Cieszkowskiego Augustyn. Biskup Hippony określał przełomową rolę Boskiego uczłowieczenia ${ }^{8}$. Tak samo jak wystąpi to w pismach Cieszkowskiego, Augustyn podkreśla doskonałość stosunków międzyludzkich w państwie niebieskim: „Nad ziemskim [państwem] - władzę ma żądza panowania w jego książętach i w tych narodach, które sobie zhołdowało; w niebieskim służą sobie wszyscy wzajemnie (...) w państwie niebieskim nie ma innej mądrości [mędrców], jeno pobożność, przez którą godnie jest czczony Bóg prawdziwy (...)" 9 .

Przejście doczesności w wieczność nie musi oznaczać wielkiej, niewyobrażalnej katastrofy. Będzie to dostosowanie czasu do wieczności (albo rozpuszczenie się czasu w wieczności). Doczesność zatem nie ustępuje miejsca Wieczności, ale przeistacza się w Wieczność. „Doczesność tedy znosi podobną abstrakcyjną wieczność, zastępując ją - zniża ją do swojego rzędu i czyni ją sobie podobną. - A nawzajem taka abstrakcyjna wieczność znosi znowu wszelką doczesność i czyni ją owszem wcale niepodobną. - Bo jeżelić owa Wieczność ma trwać wiecznie, gdzież się podzieje Doczesność? Już ona nie znajdzie ani czasu, ani miejsca dla siebie, jeżeli nie w łonie samej Wieczności? - Istnienie więc takowej doczesności obok wieczności i niezależnie od niej jest niepodobne; ona tylko we wieczności istnieć może.

\footnotetext{
kowskiego] każdy człowiek powinien mieć prawo i obowiązek żyć w pełni, czyli działać dla ogółu. Ten warunek podmiotowy zakłada całkowitą autonomię i to nie tylko w skali jednostki, lecz także wszystkich narodów. Autonomia staje się u Cieszkowskiego zasadniczą cechą nowej społeczności - społeczności »Ducha świętego《. Takiej społeczności, złożonej z autonomicznych jednostek, nie może zadowolić żaden porządek zastany, czy nadany, podobnie jak porządek idealny, czy abstrakcyjny. Prawo, które w takiej społeczności będzie miało moc obowiązującą musi być wynikiem świadomego, własnego czynu jej obywateli. Powinno się również przyczyniać do kształtowania nowych »instytucji publicznych «, inaczej do samodzielnego rozwijania życia publicznego". w: B. Markiewicz, S. Pieróg (red.), August Cieszkowski. W setna rocznicé śmierci, Warszawa 1997 , s. 44.

8 Św. Augustyn, Państwo Boże, przeł. W. Kubicki, Kęty 2002, s. 404-405.

9 Tamże, s. 546-547.
} 
- A skoroć jest lub była kiedyś jakakolwiek Doczesność, (co wyznajemy obecnem życiem), toć już owej abstrakcyjnej wieczności nigdy nie było ani być nie może, bo taż jest przez ową doczesność zawartą i wypartą" ${ }^{10}$.

Wieczność nie może być rozumiana przez pryzmat abstrakcji. Musi być przyjmowana konkretnie, nie jako to, co nastaje w kolejności po czasie doczesnym, lecz rozwinięcie, pogłębienie i lepsze zrozumienie doczesności. Doczesność z wiecznością nie są w niczym odmienne, wręcz przeciwnie, doskonale do siebie przystają. Zgodnie z postępem dialektycznym, doczesność jest pierwotnie przeciwstawna wieczności - doczesność jest realna a wieczność to stan idealny, jednak wraz z rozwojem świadomości, wieczność przechodzi ze stanu idealnego w realny. Wieczność jest ukoronowaniem światowego postępu, zsyntetyzowanie wszystkiego, co odbyło się w doczesności, a osiągnęło wyższy, lepszy poziom, stało się doskonałe. O ile w doczesności, od rwącego strumienia czasu wszystko zależało, tak w wieczności czas jest nieistotny, jest poza wiecznością. Wieczność ziemska i niebiańska, to tożsamość pojęciowa, której rozróżnienie nie należy stosować. Powiedzieć zatem, że ludzkość w przyszłości będzie żyć - pod warunkiem osiągnięcia stanu idealnego w wieczności nie jest fałszem. Lepiej jest mówić o stanie przyszłym jako wieczności realnej, której kontynuacją będzie wieczność idealna (już w zaświatach). Cieszkowski wyraźnie odstępuje od dogmatyki chrześcijańskiej, jest nieortodoksyjny, gdy ekonomię Bożą dostosowuje do ziemskiego świata. Wieczność należy pojmować jako umiejscowioną w ziemskim wymiarze, zawierającą w sobie wszystko. Pojęcie wieczności musi mieć ziemski desygnat, inaczej jest wyzute z prawdziwości, stając się mrzonką. Kategoria Nieba musi być przypisana do miejsca, aby nie zamieniła się w czystą spekulację. „I takie też Niebo, pomyślane bez Ziemi i taki Zaświat, przeciwległy rzeczywistemu Światu, równie jak Wieczność bez Doczesności, jest tylko oderwanym tworem abstrakcyjnej myśli, jest dopiero jednostronnem wywnętrzeniem się naszego Ducha. - Jest to Ogólnik bez Szczególnika, (...) i bez których ogólniki obejść się nie mogą, - słowem jest to potępienie wszelkiego ciała, i cofnięcie się w krainę czystej abstrakcji" ${ }^{11}$.

Rozpatrując historiozofię Cieszkowskiego, dostrzegamy, jak łączy z sobą filozoficzną tradycję pogańską z chrześcijańską. Wyraźny zamysł neoplatoński, głoszący eksterioryzację przedmiotów z Jedna, to nic innego jak kolejne opisy Boskiej aktywności, wpływającej na dzieje. Ów prowidencjalizm ukazywał Boga jako aktywny element w powstawaniu (i utrzymywaniu) świata; rozprowadzania boskich pierwiastków w świecie. Tak pojmowany Deus historiae, przywodzi na myśl motyw cruor Dei (krwi Pańskiej). Występujący już w archaicznych wierzeniach

10 A. Cieszkowski, dz. cyt., t. 1., s. 185.

11 Tamże, T. 2., s. 254-255. 
model teogonii, głosił poniesienie ofiary przez bóstwo, na rzecz męczeńskiego samo-z-radzania Kosmosu i przywracania siebie. Ten motyw, pod różnymi postaciami, zasilał wyobraźnię wszystkich, którzy doszukiwali się pozostałości Boskich elementów w świecie. Widoczny jest w Boskim samo-zaprzeczeniu u Eriugeny, mistyce Mistrza Eckharta, przejawia się w Ungrund Böhmego, historiozofii Bossueta, antropogonii Anioła Ślązaka, panteizmie von Baadera, procesie docierania ku Nowemu Jeruzalem u Swedenborga, i dalej, występując w ubóstwionej naturze u romantyków (choćby teozofia Schellinga). Taki sposób obrazowania świata wypływał z przyjęcia woli Bożej za wszystko odpowiadającej, mającej utajony i nieprzenikniony sens postępowania w realizacji własnego planu. Jako cześć niezgłębionej, duchowej rzeczywistości, w której uczestniczymy, należymy do jej pośledniego, zewnętrznego wytworu, naznaczonego upadkiem. Widzimy zatem, jak Bóg wpływa na los dziejów, które muszą zmierzać wytyczoną pierwotnie koleiną. W taki obraz historii wpisuje się natura grzechu i zbawienia. Konieczny był moment krytyczny - felix culpa, poruszająca bieg wydarzeń. Boska postać, wpływająca na dzieje, objawiała się pod trzema postaciami. „Cała więc Historja jest objawieniem explicite Trójcy Świętej. - W Piśmie [Świętym] zaś była dotąd trójca dopiero implicite zawarta, t.j. pojedyncze składowe jej żywioły (elementa et momenta) były w niem częścią objawione jako hypostazy już udzielonych objawień, częścią dopiero tajemniczo przepowiedziane, jako mające istotę dalszego Objawienia stanowić, - jak to było w Starym Zakonie z obietnicą Mesjasza, a w Nowym, z obietnicą Parakleta; - ale Trójcy, jako Trójcy, explicite objawionej jeszcze być nie mogło, bo spełnienie objawienia Trójcy, w trzecim jej żywiole, w trzecim jej momencie, jeszcze nie nastało, - jeszcze jako factum na świat nie wystąpiło, jeszcze dla ludzkości były nieprzystępnem" 12.

Cieszkowski czerpie wizję trynitarnego ${ }^{13}$ charakteru dziejów z bardzo długiej tradycji filozoficznej. Trzy okresy dziejów, odgrywające konieczne role na scenie

\footnotetext{
12 A. Cieszkowski, dz.cyt., s. 376-377.

13 O Trójcy Św. występującej w Jedności, a przedstawianej przez trzy periody historii pisał Augustyn: „Wierzymy, utrzymujemy i wytrwale głosimy, że Ojciec zrodził Słowo, to jest mądrość, przez którą wszystko uczynione jest; jednorodzonego Syna; jeden jednego; wieczny współwiecznego; najlepszy równie dobrego; nadto że Duch Święty jest razem Duchem Ojca i Syna, i jest on współistotny i współwieczny z obydwoma; i że to całe jest i Trójcą z powodu własności osób, i jednym Bogiem dla niepodzielnego bóstwa, jako jednym Wszechmocnym dla niepodzielnej Wszechmocy; jednakże gdy o każdym z osobna się mówi, każdy z nich Bogiem jest i Wszechmocnym; gdy zaś o wszystkich razem - nie są to trzej bogowie albo trzej wszechmogący, lecz jeden Bóg Wszechmogący; taka jest tam w trzech nierozłączalna jedność, która chciała, by tak o niej głoszono". w: Św. Augustyn, dz. cyt., s. 428.

Idea teleologii zbawienia u Cieszkowskiego jest również - grosso modo - powtórzeniem zamysłu Joachima z Fiore. Konceptu ewangelii wiecznej, kawałkującej chronologię ludzkości na epokę Ojca, Syna i Ducha Świętego. Zbieżność założeń myśliciela z Wierzenicy z italskim opatem, sprowadza się do wiary w końcowe zwycięstwo Ducha Św., poprzedzone eklezjalną jednia. Boska ekonomia zbawienia do swego celu wykorzystuje ludzkość w zbudowaniu szlaku do nowego Raju. Ziemska eschatologia odzyskania Edenu sprowadza się u obydwu do przewodniej roli Kościoła
} 
historii, muszą mieć w sobie element wspólny, wiążący wszelkie różnice, ogarniający całą ludzkość w jej przemianach. Takim punctum saliens jest osoba Jezusa Chrystusa. Zbawiciel zstępujacy na Ziemię, przyjmując ludzką powłokę, staje się równy człowiekowi, ogołacając się z Boskich atrybutów, wyznacza oś czasów, środek stworzenia. „Chrystus stanowi przeto wielką średniówkę czasów, on rozgraniczył dwa światy, czyli dwa wielkie dni świata; - On nowe stworzył Ludów i wieków pokolenie" ${ }^{14}$. W podobnym tonie zapisuje swe przemyślenia George A. Maloney: „Chrystus ukazany jest jako ośrodek jedności całego stworzonego świata. Paweł [Święty] chciałby wprowadzić nas na górę wiary, abyśmy mogli objacć wzrokiem cały znajdujący się pod nami wszechświat. Gdybyśmy podzielali jego wiarę, zobaczylibyśmy Chrystusa jako ośrodek i ogniskową, do której wpływaja i z której wypływają wszystkie byty, co potwierdziłoby Heideggerowski pogląd, że prawda jest ostatecznie pełną rzeczywistością. Wszystkie byty mają swoją ontologiczną zrozumiałość i są »prawdziwe« o tyle, o ile ujmuje się ich zależność »w istnieniu« od Ostatecznej Rzeczywistości" 15.

Osoba Chrystusa, poniosła męczeńską śmierć, by dopełnić sensu zbawienia. Pojawienie się Drugiego Adama jest ściśle związane z zagadnieniem kenozy. Proces wcielenia Chrystusa kosmicznego w postać człowieka, powinien zostać dopełniony ludzkim samo-wyrzeczeniem, którego rezultatem jest czyn. Tylko w takim stanie Duch i Natura mogą współdziałać. „Będąc w sferze wiecznego bytu Boskiego duchowym centrum powszechnego organizmu, Chrystus - wraz z opadnięciem owego organizmu na poziom strumienia zjawisk i koniecznością odbudowywania przezeń w czasie wewnętrznej jedności z Bogiem i naturą - zstępuje w ślad za nim i poddaje się również prawu bytu zewnętrznego, aby »z centrum wieczności stać się centrum historii «. (...) Będąc rzeczywistą Bogoczłowieczą Osobą, Chrystus jest w stanie zrealizować akt podwójnego zaparcia się siebie, które do pewnego stopnia ma już miejsce w ramach całego procesu kosmicznego i historycznego. Boski Logos dobrowolnie wyrzeka się tam swej chwały, porzucając pokój wieczności i podejmując walkę ze złą zasadą pośród rozmaitych perturbacji kosmicznej ewolucji oraz

\footnotetext{
Powszechnego, w którym partycypują wszyscy. Zob. L. Kołakowski, Glówne nurty marksizmu. Powstanie - Rozwój - Rozklad, Londyn 1988, s. 74.

To samo odnajdujemy u Hegla: „W rzeczywistości nietrudno w postaci samo rozszczepiającej się, w rozszczepieniu się realizującej i znowu się jednoczącej totalności, rozpoznać chrześcijańskiego Boga. Ten Bóg stworzył świat, to, co nie-Boskie, ex nihilo, tzn. z niczego stworzone, a więc z siebie samego. (...) Tym samym mysterium creationis (tajemnica stworzenia świata) wskazuje na mysterium trinitatis (tajemnicę Trójcy Świętej), ponieważ credo stanowi wyznanie »Ducha Świętego, Pana i Ożywiciela (vivificantem), który od Ojca i Syna pochodzi «". w: H. Schnädelbach, Hegel. Wprowadzenie, przeł. A.J. Noras, Warszawa 2006, s. 40-41.

14 A. Cieszkowski, dz.cyt., T. 1., s. 101.

15 G.A. Maloney, Chrystus kosmiczny od Pawla do Teilharda, przeł. T. Mieszkowski, Warszawa 1986 , s. $12-13$.
} 
objawiając się naturalnej ludzkości poprzez różne formy oddziaływania w granicach bytu skończonego. Z kolei sama natura w swoim stopniowym dojrzewaniu oraz dążeniu ku wciąż nowej percepcji Boskich form nieustannie zapiera się siebie egzystującej w formach dotychczasowych" 16.

Warto zaznaczyć, że pojęcie kenozy posiada niezwykle długą i bogatą tradycję teologiczną. Pojawia się już w dziełach - chociażby - Apolinarego z Laodycei, Grzegorza z Nyssy, Jana Chryzostoma lub Maksyma Wyznawcy, dla którego: „(...) celem egzystencji człowieka jest powrót do Chrystusa rozumiany jako uczestnictwo w Jego przebóstwionej naturze przenikniętej wspólną energią Ojca, Syna i Ducha (...) Powrót do Boga odbywa się nie poprzez symboliczne i teurgiczne akty kapłanów, ale przez żywe i świadome uczestnictwo w liturgii, będące realnym spotkaniem z Trójcą. Tym samym człowiek przestaje podlegać dionizjańskiej hierarchii i w zależności od wolnej woli może zdeterminować swoje miejsce, jest $»$ wędrującym szczeblem «. Jego spotkanie z Bogiem odbywa się na mocy łaski i indywidualnego wysiłku, gdyż Chrystus przyszedł do każdego z nas bezpośrednio, nie poprzez hierarchię" 17.

Prawda o kenozie doprowadza do właściwego sposobu istnienia osoby ludzkiej. Oznacza wyzbywanie się siebie, na rzecz odnajdywania spełnienia we wspólnocie ludzkiej. Jednakże wspólnota bez ustawicznego wsparcia Bożego byłaby niczym. Człowiek jest w stanie realizować zamierzenia Boskie za sprawą ofiarowanej mu Boskiej zasady. Jej zakorzenienie w jednostce, nie prowadzi do podporządkowania się Bogu (pewnej zwierzchniej, zewnętrznej względem Niego relacji). Zasada Boska wyzwala w człowieku wolę kreowania świata ku lepszemu, wznioślejszemu modelowi bycia. Zatem Boska zasada to pozytywna moc, sprowadzalna do treści istnienia, obejmująca sobą absolutnie wszystko. Trwanie w takiej więzi wyjawia sens Bogo-człowieczeństwa. Osoba Chrystusa wnosi odnowę w dzieje ludzkie, zawierając nowe przymierze z Bogiem. Porządek Boski uniwersalnych i ponadczasowych idei symbolizowany przez Chrystusa, przenika do doczesności. Za sprawą

16 M. Kita, Klucz do żywych przekonań. Chrystologia filozoficzna Wlodzimierza Solowjowa, Kraków 2005, s. 73, 76.

Sądzę, że warto odnotować także słowa Wacława Hryniewicza, ciekawie opisującego problem wcielenia i sensu bożo-człowieczej egzystencji: „Największym objawieniem prawdy o paschalnej strukturze osoby ludzkiej jest Chrystus. Prawda o sposobie istnienia osób Boskich objawiona została ludziom za pośrednictwem konkretnego wydarzenia, które dokonało się w dziejach Jezusa. To wydarzenie umożliwia człowiekowi poznanie w pełni osobowego istnienia Boga. Chrystus jest historycznym ucieleśnieniem i konkretnym objawieniem tego sposobu. Wcielenie i krzyż objawiają ontologiczny sens kenozy Syna Bożego. Kenoza Chrystusa ukazuje ludziom nowy sposób istnienia w pełni osobowego. Jest on niemożliwy do osiągnięcia bez ogołocenia i »opróżnienia « siebie z wszelkich przejawów egzystencjalnej samowystarczalności", w: W. Hryniewicz, Pascha Chrystusa $w$ dziejach człowieka $i$ wszechświata. Zarys chrześcijańskiej teologii paschalnej, Lublin 1991, T. 3., s. 85-86.

17 S. Swieżawski, Dzieje europejskiej filozofii klasycznej, Warszawa-Wrocław 2000, s. 371-372. 
Chrystusa człowieczeństwo staje się pojęciem granicznym - otwartym na nicość, ściągającym człowieka ku przyrodzie oraz wznosząc ku boskiej cząstce, umożliwiającej człowiekowi stanie na szczycie stworzenia i władanie różnorodnością natury. Bogo-człowieczeństwo jest zwornikiem, wiążącym elementy Boskie z bytem materialnym, pozwalając każdemu człowiekowi być istotą najgłębiej zakorzenioną w wiecznym świecie Bożym, dozwalając jednocześnie na jej odrębność i niezastępowalność w Boskim ogniwie całości. Bogo-człowieczeństwo wnosi wyjątkowość do ludzkiej egzystencji, odnosząc człowieka do nieskończoności. Chrystus to uczłowieczona Boskość i nadanie człowieczeństwa Boskości. Wcielenie było dramatem Boskiej przemiany, wymagającym przejścia - w Boskiej perspektywie - przez otchłań cierpienia, trwogi, zmysłowości i śmierci pozwalając Bogu nawiązać pełną i wieczną relację z człowiekiem. Bogo-człowieczeństwo to wzajemne samoofiarowanie Boga i człowieka. Akt wcielenia nie ma być rozumiany jako Boże samoograniczenie, czy samopowściągnięcie. W osobie Bogo-człowieczej Boskość manifestuje się przez człowieczeństwo, nie ograniczając się zewnętrznymi barierami naturalnymi. Boska wola zawarta w Chrystusie, umieszcza w ludzkim kontinuum (czaso-przestrzennym) wieczność realną, sprzężoną z wiecznością idealną, zawartą w Boskiej nieskończoności.

\section{Cieszkowski a filozofia Włodzimierza Sołowjowa}

Zgłębiając refleksje Augusta Cieszkowskiego można doszukiwać się paraleli między założeniami polskiego myśliciela a filozofią Włodzimierza Sołowjowa, który talentem i erudycją w niczym nie ustępował polskiemu filozofowi. Tak jak Polakowi, również mędrcowi rosyjskiemu była bliska wizja przebóstwienia świata, jako drogi do Królestwa Bożego. Bóg był dlań bytem centralnym, przejawiającym się i wpływającym na bieg świata. „Jeśli zaś Sołowjow pisał o ewolucji, to nadawał jej odmienne znaczenie od powszechnie używanego. Miał bowiem na uwadze głównie wolę bożą, która stanowiła istotę każdego twórczego procesu. Dlatego też ewolucja świata przechodzi przez kolejne etapy rozwoju bytu od królestwa mineralnego, w którym byt substancji przejawia się w najprostszej formie, poprzez królestwo roślinne i królestwo zwierząt aż do królestwa ludzkiego. Przypominało to schemat heglowski. Ewolucja bytu kończy się jednak królestwem Bożym, w którym człowiek powinien osiągnąć doskonałość duchową. Między poszczególnymi formami bytu i istnienia przejawiają się liczne związki, niższe dążą do wyższych, każdy jakościowo wyższy typ obejmuje także niższy. Pośrednikiem między bogiem a stworzeniem, zdaniem filozofa, był człowiek rozumiany jako forma, poprzez którą dokonuje się »przebóstwienie« (obogoczełowiecziwanije) świata. Miało to dopro- 
wadzić do połączenia ziemskości z boskością, czyli powszechnej wszechjedności. Proces rozwoju i ewolucji świata zatem to nie tylko doskonalenie się jego struktury i treści, ale również jednoczenie świata w jedną całość" 18.

Wizja świata jako upadłego Boskiego emanatu, poszukującego powrotnej drogi do duchowej ojczyzny, została rozwinięta w tekstach kabały (zwłaszcza późniejszej, czyli XVI-wiecznej, stworzonej przez Izaaka Lurię). Luria stawiał pytanie o skażenie całej natury złem. Wprowadził teorię cimcum-ograniczenia się, skurczenia Absolutu, dla uczynienia przestrzeni rodzącemu się światu. W powstałą pustkę wpadły niektóre Boskie atrybuty, i aby odbudować harmonię Bożą, zaburzoną aktem stworzenia (Boskiego wycofania), muszą zażegnać zaistniały chaos. „Zdaniem Lurii, aby zrobić miejsce dla rodzącego się świata, Ein-Sof [Absolut] zwrócił się do wewnątrz siebie, »skurczył się« lub »ograniczył« (cimcum), i tym samym stworzył miejsce, gdzie go nie ma, czyli pustkę. Przed cimcum wszystkie boskie sefiroty [rozmaite imiona boskiej natury] były połączone w sposób zgodny i harmonijny. Ale w procesie cimcum Bóg oddzielił Din od reszty swoich atrybutów i rzucił w pustą przestrzeń. Od tego momentu Din posiadł moc niszczenia. Teraz dopiero nastąpiła emanacja kolejnych sefirot i wtedy zdarzyła się katastrofa. Otóż sefiroty, aby powtórnie się nie zlać w jedność z Ein-Sof, były umieszczone w specjalnych »naczyniach« czy »skorupach«, które tworzyły rodzaj światła. Należało się z nim obchodzić bardzo ostrożnie. Ale w czasie emanacji sefirot naczynia popękały i boskie światło rozproszyło się. (...) W konsekwencji trzy najwyższe sefiroty spadły do niższych i początkowa ich harmonia została zburzona. Po tej katastrofie sefiroty skupiły się w nowych układach, które nie były już jednak aspektami Boga. Każdy z nich stał się Obliczem, w którym objawiła się cała osobowość Boga. Takim sposobem Luria znalazł sposób wyrażenia starej idei kabalistycznej, w myśl której niepoznawalny Bóg staje się Bogiem osobowym" 19. Filozofia Cieszkowskiego i Sołowjowa jest głęboko zakorzeniona w tradycji judeo-chrześcijańskiej. U obydwu łatwo doszukać się wpływów kabały, mistyki wschodniej i neoplatońskiej. „Innymi słowy: Cieszkowski w swych koncepcjach kosmogonicznych i w swej idei postępu oscylował pomiędzy gnozą, Kabałą i spokrewnionemi z niemi poglądami a ideą rozwoju, pojętą częściowo w duchu chrześcijaństwa, częściowo zaś opartej na tendencjach ewolucjonistycznych" ${ }^{20}$.

Właściwym problemem dla wspomnianych filozofów była idea Bogo-człowieczeństwa. Przestrzeń powstała między aktywną jednostką a Absolutem, wyznacza dziejowe napięcie, w którym człowiek może się realizować. Bóg wykraczający poza

18 L. Kiejzik, Wlodzimierz Sołowjow, Zielona Góra 1997, s. 110-111.

19 Tamże, s. 119.

20 M. Klepacz, Idea Boga w historiozofii A. Cieszkowskiego, Kielce 1933, s. 243. 
siebie, nie uszczupla własnej Boskości, a człowiek przekraczając siebie, umacnia człowieczeństwo. Nie chodzi zatem o Bogo-człowieczą syntezę, lecz ścisłą korelację - rodzaj uczuciowej przepaści, zatraty. Jak pisze na ten temat Sołowjow: „Więź taka [Boga z człowiekiem] byłaby niemożliwa, gdyby zasada boska miała wobec człowieka charakter czysto zewnętrzny, gdyby nie była zakorzeniona w samej jednostce ludzkiej; bez tego człowiek mógłby znajdować się względem Boga wyłącznie w stosunku podporządkowania przymusowego i fatalistycznego. Swobodna wewnętrzna więź między bezwzględną zasadą boską a jednostką ludzką możliwa jest tylko pod tym warunkiem, że również jednostka boska uzyskuje znaczenie bezwzględne. Człowiek tylko dlatego może w sposób wolny i wewnętrzny jednoczyć się z zasadą boską, gdyż sam jest w pewnym sensie czymś boskim, dokładniej - współmiernym Bogu" 21.

Bogo-człowiecza szczelina to także niepokój i dramat wolności, przy obustronnym zanegowaniu i opuszczaniu swych jedności. Zdaniem Cieszkowskiego, podobnie jak później Sołowjowa, Bogo-człowieczeństwo nie jest porzucaniem istoty ludzkiej, czy też rugowaniem elementów człowieczych, względem boskiej chwały. Bogo-człowieczeństwo to współzależność Boga i człowieka - objawienie Boga przez człowieka i wyniesienie tego, co w człowieku najwznioślejsze. Boskość jest warunkowana przez człowieczeństwo Boga, zaś człowiek dąży do potwierdzenia się w Bogu za sprawą wyrzeczenia się subiektywności oraz przejścia z różnorodności w jedność (przy jednoczesnym poszanowaniu autonomii każdego).

Kluczowa dla Bogoczłowieczeństwa jest formuła przebóstwienia (theoses), silnie powiązana z teologią prawosławną. Przebóstwienie w tradycji zachodniej jest obdarowaniem energii ludzkiej przez Boską (energia ludzka zostaje podniesiona i zrównana z Boską siłą). Natura Boska i ludzka są otwarte, wzajemnie się obdarzając i nie tracąc niczego ze swej integralności. Natomiast w tradycji wschodniej, energia Boża drzemie w człowieku i jest z niego wydobywana. Tę intuicję dobrze oddają słowa Maksyma Wyznawcy: „Łaska - czyli energie Boże, są obecne u samych podstaw bytu, są jego początkiem, ośrodkiem i celem" ${ }^{22}$. W akcie przebóstwienia człowiek dopiero osiąga siebie. Owa współzależność (synergizm) odpowiada wolności ludzkiej osoby, dzięki której może działać łaska Boża. Zatem tylko łaska ratuje naturę ludzką przed ostatecznym zepsuciem. „Łaska nie jest zatem wynagrodzeniem zasługi woli ludzkiej, jak chciał pelagianizm; ale nie jest też przyczyną »czynów zasługujących« naszej wolnej woli. Nie chodzi bowiem o zasługi, lecz o współdziałanie, o synergię dwóch woli, Boskiej i ludzkiej, o zgodną

21 W. Sołowjow, Wyklady o Bogoczlowieczeństwie, przeł. J. Dobieszewski, Warszawa 2011, s. 39-40.

22 W. Granat, Ku czlowiekowi i Bogu w Chrystusie, Lublin 1972, T. 1., s. 409. 
współpracę, w której łaska rozwija się coraz bardziej, zostaje przyswojona, »nabyta« przez osobę ludzką. Łaska jest obecnością w nas Boga, wymagającą stałych wysiłków z naszej strony. Jednak wysiłki te nie determinują bynajmniej łaski, ani też łaska nie porusza naszej wolności na wzór jakiejśs siły wyższej" ${ }^{23}$. Sołowjow przypuszczalnie znał poglądy Cieszkowskiego. Liliana Kiejzik pisze: „Jest prawdopodobne, że Sołowjow z ideami Cieszkowskiego mógł spotkać się w czasie pobytu w Polsce" 24. Warto więc prześledzić najważniejsze wątki Sołowjowskiej filozofii, celem pokazania wspomnianego podobieństwa. Kosmiczny dramat upadku i odkupienia rodzaju ludzkiego jest rozpisany - zdaniem Sołowjowa - w dziejowych aktach (człowiek współuczestniczy w Boskości, zbliżając się do niej, wypełniając się nią - motyw teandryczny). Przywodzi to na myśl tradycję chasydzką i kabalistyczną, gdzie występuje pojęcie Szechiny - zhipostazowanej obecności Boga w świecie, która w mesjańskim cyklu zbawia wszystko i wszystkich, a jednocześnie jej immanentnej stronie jest przypisana niszczycielska siła, wyczerpujacca energie stworzenia ${ }^{25}$. Świat jest skąpany w Boskiej zasadzie, obecnej w ludzkiej jaźni, wzbudzając motywację negatywną i pozytywną. Negatywna oznacza dążność do absolutnego rozwoju, przekraczanie wszelkich ograniczeń. Motywacja pozytywna domaga się pełni, zaszczepionej w świadomości idei. Sołowjowska krytyka wymierzona jest zarówno w zachodnie chrześcijaństwo (które w swojej tradycji nie rozwija wiary do końca), jak i w cywilizację niereligijną oraz ruchy socjalistyczne (w tym punkcie drogi Sołowjowa i Cieszkowskiego wyraźnie się rozchodzą), utwierdzające wiarę w człowieka, kosztem wiary w Boga, jednocześnie parodiując chrześcijaństwo - ruchy świeckie apelują o wyrzeczenie się egoizmów indywidualnych na rzecz zbiorowych, w religii natomiast samo-wyrzeczenie dopiero rozpoczyna otwarcie na wyższe pryncypia.

Sołowjow stosuje triadę w postaci: natury (całokształt rzeczywistości), Boskiej Zasady (ukryty cel i treść świata) oraz ludzkiej jaźni (podmiot życia i świadomości), prowadzącej do objawienia Boskiej Istoty. Boska Zasada na przestrzeni dziejów ujawnia się trójetapowo: początkowo występuje etap pozytywny, skrywającymi się za siłami natury (co wiąże się z politeizmem i licznymi wierzeniami czczącymi naturę), następny etap jest negatywny. W nim Boska Zasada przejawia się w odmienności od natury (etap ten charakteryzuje się pesymizmem i ascetyzmem, wyrażonym przez buddyzm). W końcowym etapie Zasada Boska przedstawia się swej osobie (w sobie i dla siebie), co wiąże Sołowjow z żydowskim monoteizmem.

23 W. Łosski, Teologia mistyczna kościoła wschodniego, przeł. M. Sczaniecka, Warszawa 1989, s. 176 .

24 L. Kiejzik, dz. cyt., s. 149.

25 Zob. G. Scholem, O mistycznej postaci bóstwa. Z badań nad podstawowymi pojęciami kabaly, przeł. A.K. Haas, Warszawa 2010, s. 215. 
Obok Boskiej Zasady, pojawiają się dwie zasady jednoczenia: Logos - Istność Boska, Najwyższa Idea oraz Sofia - Materia Boża, Ciało Boskie (obydwa elementy zespalają się w Chrystusie). Moc Sofii polega na łączeniu wszystkich elementów świata boskiego w wyniku miłości. Kosmiczny proces rozgrywa się w czasie, dążąc do udoskonalenia formy ekstensywnej, przezwyciężając formę duchową i materialną. Boski akt stworzenia, którego osnową jest wolność, ma w zamierzeniu reintegrować w Boskiej Zasadzie wszelkie wytwory Boga (mnogość wykreowanych bytów powraca do jedności Boskiego organizmu). Finalny moment kosmogonii obejmuje samoświadomość duszy ludzkiej, ukierunkowanej na projekt przekroczenia natury (przez co wyzwala się od pierwotnego upadku). Boska Zasada zradza się w duszy człowieka, oświecając go, doprowadzając do nastania nowego człowieka duchowego (teofania w ludzkim wydaniu). Wypracowana przez rosyjskiego myśliciela ontologia miłości zezwala Boskiemu Logosowi dostąpić pleromy, poprzez wyobcowujaccy akt stworzenia, w którym sofiologiczne pragnienie pojednania pozwala zatriumfować Absolutowi. Logos jest prazasadą, wyrażającą odwieczną jedność, natomiast Sofia to rodzaj „innego Absolutu” lub „Absolutu uzyskującego siebie"; Sofia wprowadza zasadę jedno-wielości (jak u Plotyna: Hen Jedno i Aoristos Dyas - Nieokreślona Diada). Mistycznie zdobywana Prawda (jako wieczna i nieporuszona) posiada status bycia, oddawany przez Sołowjowa trudnym do przetłumaczenia słowem cyщee, oznaczającym bycie, bytujące, albo to, co istnieje (prawdziwa istność) - prapoczątek wszystkiego; przejaw apodyktycznej jedności, ujawniającej się w bytach pojedynczych oraz złożonych, wykraczające poza całe istnienie. Absolut niezmienny w formie, uczestniczy w procesie historii (jest jej podmiotem), zaś historia sama w sobie jest procesem - to symbioza Absolutu ze światem; uczestnictwo świata w rozwoju całej materii do ostatecznej wszechjedności.

Tematyka Sofii objaśnia fenomen zła, jawiącego się pod spersonifikowaną postacią Szatana, ścierającego się z Demiurgiem na przestrzeni trzech okresów: kosmicznego, mitologicznego i historycznego. Dopiero od czasu uczłowieczenia Boga, w osobie Chrystusa, pozycja zła zmalała. Aby ostatecznie odnieść zwycięstwo nad złem, powinno się zabiegać o pojednanie Kościoła Wschodniego z Zachodnim (rozbicie ładu wewnątrzkościelnego nastąpiło w przypadku Kościoła Zachodniego przez uleganie pokusie władzy świeckiej, zaś w przypadku Wschodniego na trzymaniu się wyłącznie strony teoretycznej praw wiary). W ramach postępującej sakralizacji kultury ludzkiej ma nastąpić dalszy czas Bogo-człowieczeństwa. Zapoczątkowaniem wszechjedności okaże się unia Kościoła prawosławnego z katolickim. Żywioł boski skrywający się w Kościele przenika ludzkie namiętności. Powstaje zbiorowość wykraczająca poza granice państwowości, poświęcając się celom Nieba. Nastaje teokracja, w której każdy będzie realizował wewnętrzną moc Boga, zaś historia profana znajduje swój ciąg w historia sacra. 


\section{Kościół Powszechny}

Nadchodzaca trzecia epoka to czas Parakleta - Ducha Pocieszyciela, przynoszącego Prawdę o historii, wieńcząc ją. Religia Parakleta (inspirowana mesjanizmem saintsimonistycznym ${ }^{26}$ ) ma całkowicie przekształcić dotychczasową religijność, wykazując jej braki. Religia przyszłości ma być absolutna, czyli zawierać w sobie całą wiedzę. Kult nowej religii przekształcony zostanie w działalność estetyczną (sztukę), natomiast dogmatyka zostanie wyparta przez naukę. „Innymi słowy przyszła religia, będąca naprawdę »katolicką«, tj. powszechną, będzie po prostu spełnieniem całego historycznego ciągu rozwojowego poszczególnych religii, ich kontynuacją (bezpośrednio kontynuacją chrześcijaństwa oczywiście), ale nie jako jedno z ogniw łańcucha, lecz jako cel, ku któremu łańcuch prowadzi. Dlatego to w przyszłości zaniknąć muszą (a raczej, powiedzmy, zniesione być muszą) te formy życia religijnego, które dotychczas uznawano za konieczne. Tak więc zaginie stan pośredników między Bogiem a wiernymi - kapłani, duchowieństwo. Jednakże zaniknąć ma w tradycyjnym sensie nie tylko ta sfera religijności, którą nazywamy organizacją, lecz także zmienić mają swój wymiar dwie pozostałe sfery: doktryna i kult (obrządek)" 27.

Kościół Powszechny - w zamyśle Cieszkowskiego - niesie obietnicę apokatastazy. Kościół ten ma wyzwolić żywioł wiary, dotychczas ograniczanej instytucjonalnymi sporami. Ma także zebrać w sobie wszystkich (Cieszkowski zakłada, że wszyscy staną się religijni, gdyż niepodobna być niereligijnym; areligijność jest równa aspołeczności ${ }^{28}$ ). „Jak tedy Kościół Chrześcijański ogarnąć miał idealnie wszystkich ludzi, tak Kościót Ludzkości ogarnąć ma realnie wszystkie ludy i połączyć takowe nie żadną trafunkową przyrodzoną siłą, ani też abstrakcyjno-idealnym nakazem, - ale organicznem życiem. Nie idzie mu bynajmniej o spojenie ludów w jedno olbrzymie a ogólne państwo, - ale właśnie o rozwinięcie wspólnej państw Jedności, - o ich wiekuistą Harmonję" 29. Podobnie pisał

\footnotetext{
26 A. Walicki, Filozofia polskiego romantyzmu, Kraków 2009, s. 71-72.

27 M.N. Jakubowski, Czyn, Przyszłość, Naród. Poglądy filozoficzne Augusta Cieszkowskiego, Warszawa-Poznań 1989, s. 65-66.

28 Taki sposób myślenia jest naiwną utopią, jednak są badacze zajmujący odmienne stanowiska: „Filozofia Cieszkowskiego nie jest utopią, dlatego że wydaje się on w pełni świadomy, iż pełna harmonia społeczna, a więc Królestwo Boże, wymagałaby nawrócenia wszystkich z osobna wolnych »duchów«. Owszem, jest przekonany, że nawracać się będą w tym sensie już niedługo całe społeczności, a więc jego ocena rzeczywistości oraz najbliższej mu przyszłości była zdumiewająco, a nawet szokująco optymistyczna. I w tym punkcie, ale też tylko w tym, polski filozof wydaje się niepoprawnym marzycielem. Z drugiej jednak strony nawet najmniejszy gest miłosierdzia, konkretna pomoc okazana konkretnemu człowiekowi, jakoś jednak to Królestwo Boże realnie przybliża oraz buduje", W. Sajdek, Postęp bez rozboju: podstawy teorii dynamizmu spolecznego w filozofii Augusta Cieszkowskiego, Lublin 2008, s. 20.
}

29 A. Cieszkowski, dz. cyt., T. 3., s. 58. 
Sołowjow: „Lecz idea ta [zjednoczonej ludzkości] stała się ciałem, kiedy absolutny środek wszystkich istot został odkryty w Chrystusie. Od tej pory wielka ludzka jedność, powszechne ciało Bogoczłowieka, istnieje realnie na ziemi. Nie jest ono doskonałe, ale istnieje; dąży do doskonałości; rośnie i rozszerza się na zewnątrz i rozwija się wewnętrznie. Ludzkość nie jest już bytem abstrakcyjnym, jej forma substancjalna w świecie chrześcijańskim, w Kościele powszechnym. (...) Uczestniczyć w życiu Kościoła powszechnego, w rozwoju wielkiej cywilizacji chrześcijańskiej, uczestniczyć w tym na miarę sił i własnych zdolności oto jaki jest jedyny prawdziwy cel, jedyna prawdziwa misja wszelkiego narodu. To oczywista i elementarna prawda, że idea jednego organizmu nie może izolować go i ustawiać w pozycji konfliktowej wobec innych organizmów, ale że stanowi ona podstawę jego jedności i solidarności ze wszystkimi częściami żywego ciała. Z chrześcijańskiego punktu widzenia nie należy poddawać w wątpliwość zastosowania tej zupełnie elementarnej prawdy do całej ludzkości, która jest żywym ciałem Chrystusa" 30.

Kościół powszechny to najdoskonalszy obraz życia wspólnotowego - osiągnięcie wspólnoty wszechjednej i wszechwiecznej. Członkowie Kościoła powszechnego uzyskują najwyższą formę rozwoju, wyzbytą błądzenia i w pełni wolną. Stają się aktem ostatecznym - urzeczywistnieniem prawdy. Zamysł Cieszkowskiego i Sołowjowa dobrze oddają słowa Włodzimierza Łosskiego, stwierdzającego, że: „Kościół wzrasta i tworzy się w historii, wprowadzając do swej wspólnoty, jednocząc z Bogiem wybranych. Świat starzeje się i grzybieje, podczas gdy Kościół jest nieustannie odmładzany i odnawiany przez Ducha Świętego, który jest źródłem jego życia. W określonym momencie, gdy Kościół osiągnie pełnię swego wzrostu ustaloną wola Boga, świat zewnętrzny, wyczerpawszy swe zasoby życiowe, umrze, a Kościół ukaże się w swej wiecznej chwale jako Królestwo Boże. Objawi się więc jako prawdziwa podstawa stworzeń, które zmartwychwstaną jako niezniszczalne, aby cieszyć się jednością z Bogiem, który stanie się wszystkim we wszystkich. (...) Jedni będą przebóstwieni za przyczyną energii, które uzyskali dla wnętrza swego bytu, inni pozostaną poza łaską i dla nich przebóstwiający ogień Ducha będzie płomieniem zewnętrznym, płomieniem nie do zniesienia dla wszystkich tych, których wola opiera się Bogu. Kościół jest więc miejscem, gdzie w życiu obecnym dokonuje się zjednoczenie z Bogiem, zjednoczenie, które spełni się w życiu przyszłym, po zmartwychwstaniu umarłych" 31.

Kościół powszechny urzeczywistnia nastanie Królestwa Bożego na ziemi. Teokracja zaproponowana przez Cieszkowskiego i Sołowjowa ma być dowodem wol-

30 W. Sołowjow, Zaślubiny Wschodu z Zachodem, przeł. F. Memches, Warszawa 2007, s. 39.

31 W. Łosski, dz. cyt., s. 159. 
ności, miłości i oddania Boga, odbitego w stworzeniu. Teokracja to urealnienie indywidualnego Bogo-człowieczeństwa, z przewodnią rolą Kościoła „właściwego” - kapłaństwa.

\section{Zakończenie}

Filozofia Augusta Cieszkowskiego w zestawieniu z motywami podejmowanymi przez Włodzimierza Sołowjowa jest próbą ukazania działalności Boga poprzez prawa dziejów. Historiozofia tak pojmowana podkreśla istotny wkład człowieka w kształtowaniu doczesności, dążąc do ideału nieskończoności pośród skończonych bytów. Wyraża wpisanie Absolutu w rzeczywistość, którą pochłania, przy jednoczesnym zawiązaniu relacji z człowiekiem. Omawiani myśliciele są zgodni w przyznaniu Boskiemu wcieleniu kluczowego znaczenia w procesie zbawienia świata i człowieka. Kenoza to przełomowy moment, utrwalajaccy Bożo-człowiecze przymierze. Ludzkość - główny bohater historii - jest środkiem do finalnego objawienia okruchów Boskości pozostawionych w świecie i człowieku, czyniąc z ludzi narzędzie do swoistego, antropologicznego objawienia - nośnika woli Bożej, przejawiającej się w uczuciu, woli i czynie. Historia jako domena ludzkości jest w koncepcji Cieszkowskiego i Sołowjowa uzupełniona naczelną rolą Boga wraz z ziemskim odpowiednikiem - Kościołem. „Nie ma historii Boga; jest historia świata, kosmosu, a właściwie historia człowieka, historia ludzkości. Historia ta może być chaosem nicościującego przemijania, a więc czymś, co tylko czysto formalnie nazwać można historią, ale może być również sensownym procesem, dokładającym do Absolutu pewną zbędną dla niego, ale niezbędną dla człowieka - w jego ponaddoraźnym ukierunkowaniu na to, co absolutne - nadwyżkę. Właśnie zbędność, niekonieczność tej nadwyżki dla Absolutu nadaje jej szczególny wobec Absolutu walor - walor wolności, dobrowolności i miłości wobec Boga, potwierdzający zarazem i urzeczywistniający wolność, dobro i miłość Boga" 32. Boska „nadwyżka”, zaszczepiona w człowieku, ujawnia nie tylko ludzki potencjał, ale przyznaje, że właściwym podmiotem rozwoju historycznego jest wzajemna relacja Absolutu i człowieka. Jedynie Bogo-człowiecza unia pozwala wypracować wspólne korzyści, dając istotne dopełnienie Bogu i człowiekowi, których natury mogą wzajemnie rozwijać się i uzupełniać w kosmicznym procesie pojednania.

\footnotetext{
32 J. Dobieszewski, Wtodzimierz Solowjow. Studium osobowości filozoficznej, Warszawa 2002, s. $157-158$.
} 


\section{The sense of history and kenosis in August Cieszkowski's and Vladimir Solovyov's thought}

\section{Summary}

August Cieszkowski was one of the brilliant Polish thinkers of the nineteenth century, who combined Hegel's philosophy with Christian mysticism. The main subject of this text is a presentation of the role of kenosis in a historical perspective and the category of future, which means the union of humanity, end of time and creating The Common's Church. Additionally, I am going to show the relation between Cieszkowski's and Vladimir Solovyov's philosophy (especially the theory of Godmanhood). Both views are similar and search, in their criticism of Hegel's system, for a way to messianistical redemption. The purpose of the comparison is to indicate the similarities in the philosophy of August Cieszkowski and Vladimir Solovyov, relating to the problem of a sense of history and kenosis.

Key words: Cieszkowski, Solovyov, Christian mysticism, Hegel's philosophy

Słowa kluczowe: Cieszkowski, Sołowjow, mistycyzm chrześcijański, filozofia Hegla

\section{Bibliografia}

August Cieszkowski. W setna rocznice śmierci, Barbara Markiewicz, Stanisław Pieróg (red.) Warszawa 1997.

Augustyn św., 2002, Państwo Boże, przeł. W. Kubicki, Kęty 2002.

Bartula P., „Jako w niebie tak i na ziemi”: August Cieszkowski redivivus, Kraków 2006.

Cieszkowski A., Ojcze nasz, T. 1-3, Poznań 1922-1923.

Cieszkowski A., Prolegomena do historiozofii, Poznań 2007.

Dobieszewski J., Włodzimierz Sołowjow. Studium osobowości filozoficznej, Warszawa 2002.

Granat W., Ku czlowiekowi i Bogu w Chrystusie, T. 1, Lublin 1972.

Hellwig J., Cieszkowski, Warszawa 1979.

Hryniewicz W., Pascha Chrystusa w dziejach człowieka i wszechświata. Zarys chrześcijańskiej teologii paschalnej, T. 3., Lublin 1991.

Jakubowski M.N., Czyn, Przyszłość, Naród. Poglady filozoficzne Augusta Cieszkowskiego, Warszawa - Poznań 1989.

Jakubowski M.N., Historiozofia jako filozofia praktyczna. Hegel a polska filozofia czynu, Bydgoszcz 1991.

Jakubowski M.N., Narodowe $i$ Uniwersalne. Cztery studia o polskiej filozofii politycznej doby romantyzmu, Toruń 2002. 
Keller J., Czyn jako wyraz postawy moralnej A. Cieszkowskiego, Lublin 1948.

Kiejzik L., Włodzimierz Sołowjow, Zielona Góra 1997.

Kita M., Klucz do żywych przekonań. Chrystologia filozoficzna Włodzimierza Sołowjowa, Kraków 2005.

Klepacz M., Idea Boga w historiozofii A. Cieszkowskiego, Kielce 1933.

Kołakowski L., Gtówne nurty marksizmu. Powstanie - Rozwój-Rozkład, Londyn 1988.

Kowalczyk S., Koncepcja absolutu w pismach Hegla, Lublin 1991.

Kuczyński J., 1976, Homo Creator. Wstęp do dialektyki człowieka, Warszawa 1976.

Łosski W., 1989, Teologia mistyczna kościoła wschodniego, przeł. M. Sczaniecka, Warszawa 1989.

Maloney G.A., Chrystus kosmiczny od Pawła do Teilharda, przeł. T. Mieszkowski, Warszawa 1986.

Przebinda G., Między Moskwa a Rzymem. Myśl religijna w Rosji XIX i XX wieku, Kraków 2003.

Przebinda G., Włodzimierz Solowjow wobec historii, Kraków 1992.

Sajdek W., Postep bez rozboju: podstawy teorii dynamizmu społecznego w filozofii Augusta Cieszkowskiego, Lublin 2008.

Schnädelbach H., Hegel. Wprowadzenie, przeł. A.J. Noras, Warszawa 2006.

Scholem G., O mistycznej postaci bóstwa. Z badań nad podstawowymi pojęciami kabały, tłum. A.K. Haas, Warszawa 2010.

Serwatowski W., Kulski G., Królestwo Boże w romantycznych interpretacjach: August Cieszkowski, Poznań 1995.

Sojka M., Neomesjanizm a recepcja Cieszkowskiego, Wrocław 1986.

Sikora P., Logos niepojęty. Analiza filozoficzna, Kraków 2010.

Stachurski L., Heglizm polski: elementy strukturalne, Warszawa 1998.

Sołowjow W., Wyktady o Bogoczłowieczeństwie, przeł. J. Dobieszewski, Warszawa 2011.

Sołowjow W., Zaślubiny Wschodu z Zachodem, przeł. F. Memches, Warszawa 2007.

Swieżawski S., Dzieje europejskiej filozofii klasycznej, Warszawa-Wrocław 2000.

Walicki A., Filozofia polskiego romantyzmu, Kraków 2009.

Wawrzynowicz A., Filozoficzne przesłanki holizmu historiozoficznego w myśli Augusta Cieszkowskiego. Poznań 2010.

Woszczyk A., Problem hen i aoristos dyas $w$ Enneadach Plotyna, Katowice 2007.

Michał Sikora - doktorant w Zakładzie Historii Filozofii Nowożytnej i Współczesnej Uniwersytetu Śląskiego w Katowicach.

Adres korespondencyjny: platon87@tlen.pl 